\title{
CONSTRUCTION OF A SHUTTLE VECTOR BETWEEN E.COLI AND
} B. SUBTILIS

\author{
Iyad Qassar \\ Department of Biology, College of Science, University of Sulaimani, Sulaimani, \\ Kurdistan Region of Iraq.
}

\begin{abstract}
A stable shuttle vector was constructed by ligating plasmid pNO1523 with plasmid pUB110. The new vector, pNU2, approximately $9.4 \mathrm{~kb}$ was capable of replicating in both E.coli and B. subtilis. The shuttle vector confers ampicillin and kanamycin resistance for E.coli and kanamycin resistance for B. subtilis.

Transformation frequency was $4 \times 10^{2}$ transformants per microgram of DNA in competent B. subtilis.

Restriction enzyme analyses of the vectors isolated from both microorganisms showed that they were identical. Also, the shuttle vector is stable for insertional inactivation and carries many unique restriction sites located outside the antibiotic resistance genes.
\end{abstract}

\section{Introduction}

The genus Bacillus is an important source for production of a variety of industrially important extracellular enzymes eg: neutral proteases and amylases. Also, it plays a significant role in the commercial production of antibiotics and insecticides (Palva; 1982, Hardy; 1986; Schallmey et al., 2004). (1-3).

The ability to introduce plasmid DNA into bacterial cells by transformation has been of central importance to the recent rapid advances of molecular biology and to the DNA-cloning technology. Since, gene cloning system in $E$. coli was established, the gram-positive $B$. subtilis has received increasing attention as a possible host for recombinant DNA (Chang and Cohen, 1979).(4).

Several plasmids of Staphylococcus aureus have been introduced into $B$. subtilis. They were found to be stable, can replicate and express resistance to different antibiotics in the host cell. Furthermore, they have been used for molecular cloning (Kishida et al., 1987, Grkovic, et al., 2003). (5,6). Some Bacilli plasmids (pC $194 \mathrm{Cm}^{\mathrm{r}}$; pUB $110 \mathrm{Km}^{\mathrm{r}} \mathrm{pE} 194$ $\mathrm{Em}^{\mathrm{r}}$ ) were reconstructed with one another to confer resistance to two antibiotics (Gryczan et al., 1980) (7). Also they were combined with E. coli plasmids (pBR $322 \mathrm{Ap}^{\mathrm{r}} \mathrm{Tc}^{\mathrm{r}} \mathrm{pMB} 9 \mathrm{Tc}^{\mathrm{r}}$ ) and the produced shuttle vectors were maintained in E. coli and B. subtilis (Imanaka et al., 1981; Kishida et al., 1987; Takimoto et al.,1999).(8, 5, 9) Moreover, some of the shuttle vectors capable of replication in $E$. coli and in Clostridium have been reported (Kim and Blaschek 1989; Truffaut et al., 1989; Yashino et al., 1990, Theys et al., 1999). (10-13) In this report, we construct a shuttle vector pNU 2, from E. coli plasmid pNO 1523 (Dean, 1980) (14)and B. subtilis plasmid pUB 110 (Gryczan, et al., 1978)(15) which could be used for molecular cloning in both species providing insertional inactivation characteristics.

\section{Materials and Methods:}

\section{Bacterial strains and media}

LB medium (g/L Tryptone, $10 ; \mathrm{NaCl}, 10$; Yeast extract, 5) was used to grow E. coli and B. subtilis.

B.subtilis (ATCC 33608) and E. coli MC 1009 (Pharmacia) were used as host cells for the hybrid plasmid pNU2. Plasmid pUB 110 was isolated from B. subtilis pUB 110 (ATTC 37015) whereas, pNO 1523 was isolated from E.coli MC1009.

\section{Plasmid preparation}

Plasmid DNA was prepared according to the CTAB method (Del-Sal et al., 1989) (16) with slight modification as follows: the cells were suspended in half vol. of STE buffer $(10 \mathrm{mM}$ Tris. $\mathrm{Cl} \mathrm{pH} 8,100 \mathrm{~m} \mathrm{MNaCl}$, 1mMEDTA pH8) containing RNase and lysozyme. After $10 \mathrm{~min}$ incubation at room 
temperature, the second half of STE containing . $2 \%$ SDS was added.

\section{Enzymatic digestion and ligation}

Enzymes were purchased from Bohrenger and Mannheim. All enzymatic reactions were performed according to the company's specifications. Plasmids pNO1523, pUB 110 were cleaved separately by the endonuclease EcoRI and the cleavage products were examined on agarose gel. $2 \mu$ lof each plasmid mixed and the mixture was treated with $\mathrm{T} 4$ DNA ligase, in a volume of $10 \mu \mathrm{l}$ ligation buffer. At the end of the 48 hours incubation time, the ligation mixture was examined on agarose gel to be sure that ligation has actually occurred, then used to transform $E$. coli.

\section{Transformation}

Transformation of $E$. coli was performed according to the heat shock method (O'Connel, 1984) (17). Transformed cells were selected on $(50 \mathrm{mg} / \mathrm{ml})$. The presence of a recombinant plasmid was examined on kanamycin plate $(25 \mu \mathrm{g} / \mathrm{ml})$ by replica plating. Transformation of $B$ subtilis (try C2 his B2) (ATCC37015) with the hybrid plasmid pNU2 was carried out as follows: competent cells of B. subtilis were prepared as described by Hardy (1968) (2) except for the addition of the amino acids; tryptophan and histidine (concentration of each; $50 \mu / \mathrm{ml}$ and $5 \mu / \mathrm{ml}$ for the first and the second growth media, respectively). Plasmid DNA $(1 \mu \mathrm{g})$ was added to $1 \mathrm{ml}$ suspension of the competent cells and incubated at $37{ }^{\circ} \mathrm{C}$ for $45 \mathrm{~min}$. The suspension was centrifuged and cells were resuspended in LB broth and incubated at $37^{\circ} \mathrm{C}$ for $2 \mathrm{hrs}$. Transformants of B. subtilis were selected on LB-agar containing $5 \mu \mathrm{g} / \mathrm{ml}$ kanamycin.

\section{Agarose gel electrophoresis:}

Performed in $0.6 \%$ agarose in TE buffer (g/L: Tris-base, 10.9; Boric acid, 5.56; $\mathrm{Na}_{2}$ EDTA, 0.75; $\mathrm{pH} 8.2$ ) at 60 volts for $3 \mathrm{hrs}$. Gels were stained with ethidium bromide $(0.5 \mu \mathrm{g} / \mathrm{ml})$ and photographed using Polaroid film type 667 .

\section{Phenotypic stability of plasmid:}

Diluted samples of transformed cells were plated on LB agar containing ampicillin
$(50 \mu \mathrm{g} / \mathrm{ml})$ for $E$. coli or kanamycin $(5 \mu \mathrm{g} / \mathrm{ml})$ for B.subtilis. A fresh colony was inoculated in $50 \mathrm{ml} \mathrm{LB}$ broth containing the appropriate antibiotic as a preculture and incubated at $37^{\circ} \mathrm{C}$ until late exponential phase. A sample of which transferred to antibiotic-free LB-broth at about 100 cells $/ \mathrm{ml}$ and incubated for about 10-12 hrs with vigorous shaking. Diluted aliquots were plated on antibiotic-free medium. After formation, colonies were transferred by replica plating to LB-agar containing either antibiotic to determine plasmid stability.

\section{Results and Discussion:}

In order to identify the recombinant plasmid, cleared lysates were subjected to gel electrophoresis analyses and a single recombinant plasmid was chosen; larger in size than any of the parental plasmids.

Digestion with EcoRI produced two bands, which corresponded in size with linearized pUB 110 and pNO 1523 controls respectively (Fig. 1, C, D, E, F). Moreover, linearization with Hind III revealed a single band indicating that the vector carries only one copy of pNO 1523. Also, size measurements using $\lambda$-Hind III digest revealed that the plasmid is approximately $9.4 \mathrm{~kb}$ Fig. (1.A); the size expected as a result of combining a single copy of the parental plasmids $($ pNO $1523=4.9 \mathrm{~kb}, \mathrm{pUB} 110=4.5 \mathrm{~kb})$. The recombinant was referred to as pNU2.

Transformation efficiency with $B$. subtilis with the pNU2 was found to be $4.2 \times 10^{2}$ colonies $/ \mu \mathrm{g}$ DNA on $5 \mu \mathrm{g} / \mathrm{ml}$ kanamycin. Such a low efficiency may be attributed to the monomer form of the plasmid (Clover, 1984) (18).

It is important to note that selection of transformed $B$. subtilis with pNU2 using ampicillin was unattainable in spite of the existence of an intact $\beta$-lactamase gene. However, growth was observed on plates containing $50 \mu \mathrm{g} / \mathrm{ml}$ ampicillin following streaking of such transformed cells previously selected on kanamycin. Similar results reported by Imanaka et al., (1981) (8) since they were able to determine a threshold for ampicillin resistance at $20 \mu \mathrm{g} / \mathrm{ml}$ by the transformed B. subtilis. 
Stability tests indicate that the shuttle vector is stable in both hosts since the removal of antibiotic from the media did not affect its existence. Moreover, pNU2 may be isolated from fully grown cultures of the two species with a yield of about $1.0 \mu \mathrm{g}$ per $1.5 \mathrm{ml}$ of culture. This permits us to conclude that the plasmid exists in a high copy number.

The vector pNU2, has a unique restriction site for $\mathrm{Bgl}$ II on the kanamycin resistance gene which renders it suitable for insertional inactivation. It also harbors unique restriction sites for the endonucleases, Sma I, Hpa I, Sst II, Xba I, Hind III, and Pvu II located outside the antibiotic resistance genes Fig. (2)

Finally, the shuttle vector was maintained and can be used directly for gene cloning between $E$. coli and B. subtilis.

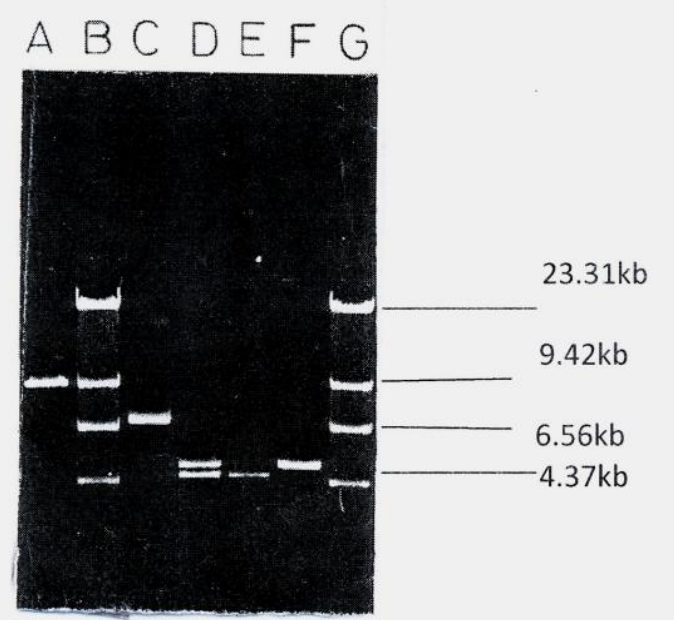

Fig. (1) : Agarose gel electrophoresis of plasmids:

A- pNU2 digested with Hind III.

B- $\lambda$ - DNA digested with Hind III.

C- pNU2-cce.

D- pNU2 digested with Eco RI.

E- pUB 110 digested with Eco RI.

F- pNO 1523 digested with Eco RI

G- $\lambda$ DNA digested with Hind III.

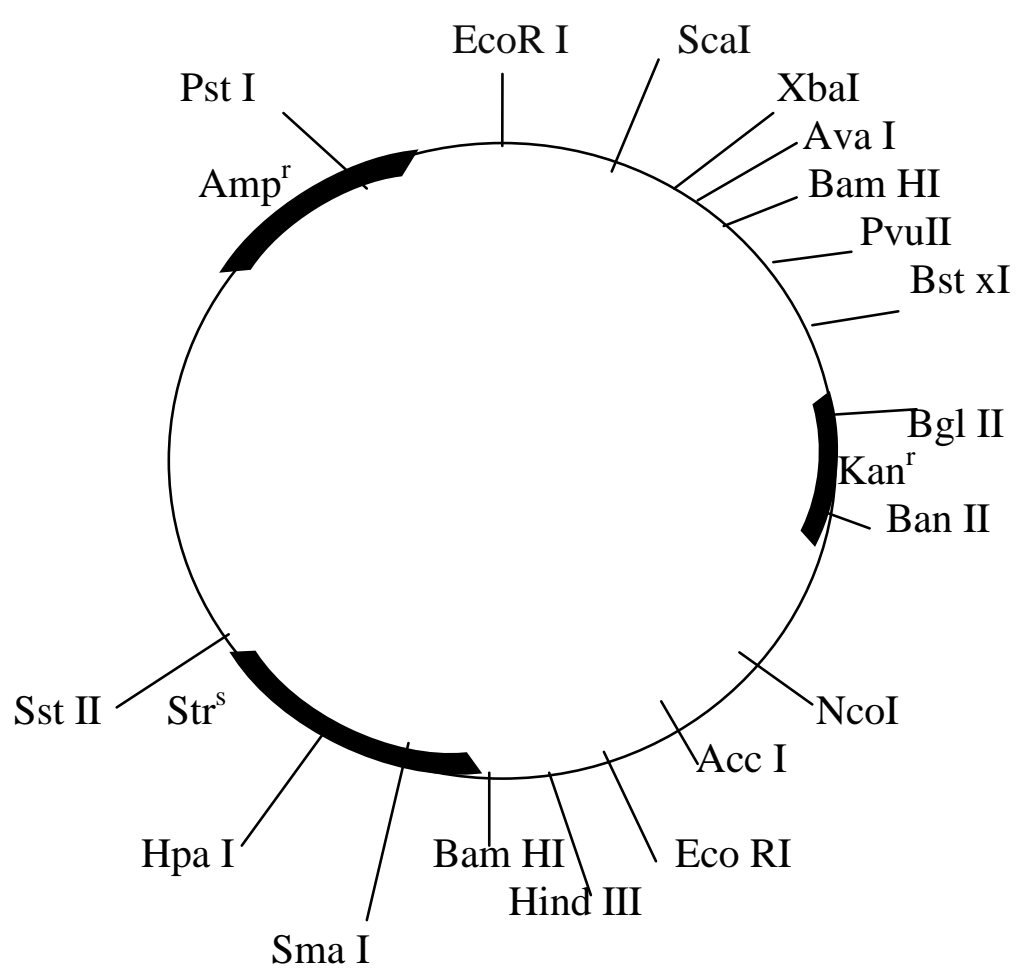

Fig. (2) : The constructed shuttle vector pNU2, showing the various restriction sites. 


\section{References}

[1] Palva,I. (1982). Molecular cloning of $\alpha$ - amylase gene from Bacillus amyloliquefaciens and its expression in Bacillus subtilis. Gene. 19, 81-87.

[2] Hardy, K.G. (1986). DNA cloning Vol II IRL-Press. Oxford.

[3] Schallmey, M., Singh, A. and Word, O.P. (2004.) Development in the use of Bacillus species for industrial production. Canadian J. of Microbiol. 50 No.1: 1-17.

[4] Chang, S. and Cohen, S.N. (1979). High frequency transformation of Bacillus subtilis protoplast by plasmid DNA Mol. Gen. Genet. 168, 111-115.

[5] Kishida, H., Tojo, T. and Maruo, B. (1987). Molecular cloning of $\alpha$-amylase gene from a mutant of Bacillus licheniforis and its expression in various strains. J. Gen. Appl. Microbiol. 33, 355-362.

[6] Grkovic, S., Brown, M.H., Hardie, K.M., Firth, N. and Skurray, R.A. (2003). Stable low copy number Staphylococcus aureus shuttle vectors. Microbiol. 194, 785-794.

[7] Gryczan, T.J., Shivakumar, A.G. and Dubnau, D. (1980). Characterization of chimeric plasmid cloning vehicles in Bacillus subtilis. J. Bacteriol. 141, 264253.

[8] Imanaka, T., Tsunekawa, H. and Aiba, S. (1981). Cloning of genes for penicillinase; pen $\mathrm{P}$ and pen I, of Bacillus licheniformis in some vector plasmids and their expression in, Escherichia coli Bacillus subtillis and Bacillus licheniformis. J. Bacteriol. 147, 776-786.

[9] Takimoto, A., Yagi, S. and Mitsushmak, K.(1999). High level of expression, purification, and some properties of a recombinant cephalosporin $\mathrm{C}$ deacelytase.

[10] --Kim, A.Y. and Blaschek,H.D. (1989). Construction of an E. coli- Clostridium prefringens shuttle vector and plasmid transformation of Closridium perfringens. Appl. Environ. Microbiol. 55, 360- 365.

[11] Truffaut, N. Hubert, J. and Reysset, G. (1989). Construction of a shuttle vector useful for transforming Clostridium acetobutylicum. FEMS Microbiol. Lett. 58, 15-20.

[12] Yoshino, S. Yoshino, T. and Hara, S. (1990). Construction of a shuttle vector plasmid between Clostridium acetobutylicum and Escherichia coli. Agric. Chem. 54, 437-441.

[13] Theys, J., Nuyts, S., Landuyt, W., Van Mellaer, L., Dillen, C., Bohringer, M., Durre, P., Lambin, P.and Anne, J. (1999). Stable Eschericia coli-Clostridium acetylbutylicum shuttle vector for secretion of murine tumor necrosis factor Alpha. Appl. J. Microbiol.. 65 No.10 :4295-4300.

[14] Dean, D. (1981). A plasmid cloning vector for direct selection of strains carrying recombinant plasmids. Gene. 15, 99-102.

[15] Gryczan, T. J., Contente, S. and Dubnau, D. (1979). Characterization of Staphilococcus aureus plasmids introduced by transformation into Bacillus subtilis. J. Bacteriol. 134, 318-329.

[16] Del-Sal, G.D., Manfioletti, G. and Schneider, C. (1989). The CTAB-DNA preparation method: A common mini-scale preparation of template DNA from phagemids, phage or plasmids suitable for sequencing. Biotechniques. 7: 1089-1093.

[17] O'Connell, M.P. (1984). Advanced Molecular Genetics. Springer-Verlag, New York.

[18] Glover, D.M. (1984). Gene cloning. Chapman and Hall, London.

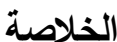

تم بناء ناقلة جينات مكوكيه، مستقره بواسطة ربط

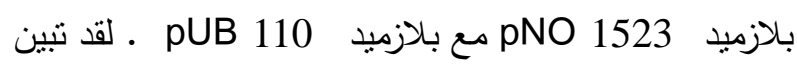

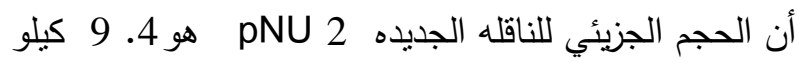

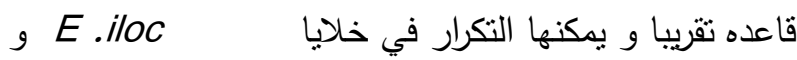
م . silitbus . مكا أن لها القدره على منح خلايا E .iloc uubtilis s. B كان تردد التحول لخلايا DNA silitbus و قد تبين من تحليل الانزيمات القاطعه للتاقله المعزوله من كلنا الخليتين المتحولتين أن البلازميد منماتل. كذلك فأن الناقله المكوكيه

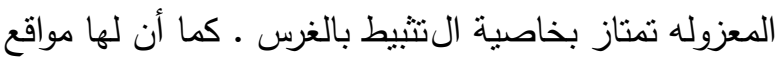
قطع احاديه خارج الجينات المقاومه لعضادات الحيويه. 